\title{
THE MUSLIM/MUDEJAR IN THE CANTIGAS OF ALFONSO X, EL SABIO
}

Por

RHONA ZAID

A great deal of current interest has been sparked regarding Alfonso $X$ 's attitudes towards the various minorities which comprised his dominions (1). An excellent place to begin any serious re-assesment of alfonsine ideas of tolerance and intolerance is provided by the Cantigas of Santa Maria, the king's greatest contribution to medieval art and letters.

Castilian society, as a whole under Alfonso, at this time was marked by a degree of religious identification of an intensity unknown in the rest of Europe (Payne 136). At first the Reconquest may have been largely a political and military enterprise to recover what had been Hispano-Christian territory (2). But the ensuing acceptance of a degree of "toleration» did not imply relativism or equality, for Castilian Christians were firmly convinced of the religious inferiority as well as the legal inferiority of the Muslims and Jews (3).

(1) For the Muslims and/or Jews as minority group(s), see: MARJORIE RATCLIFFE, "Judios y Musulmanes en las Siete Partidas de Alfonso $X$, el Sabion, in Alfonso $X$ el Sabio: Vidas, Obras, Época: Consejo Superior de Investigaciones cientificas: Madrid, 1984; DWAYNE E. CARPENTER, "Alphonsine Spain: A Commentary on Book VII, Title XXIV, Law 8 of las Siete Partidas", Kentucky Romance Quarterly, in progress. J. S. GEARY, et al, "Tolerance and Intolerance: Alfonso X's Attitudes towards Synagogues as Reflected in las Siete Partidas", Kentucky Romance Quarterly 31 (1984): 31-39; A. H. and H. E. CUTLER, The Jew as Ally of the Muslim: Medieval Roots of Anti-Semitism, University of Notre Dame, 1986 . Specific material regarding minorities in the Cantigas is covered quite thoroughly by ALBERT I. BAGBY in his Ph. $D$. dissertation, "The Moor and the Jew in the Cantigas of Alfonso X, el Sabion, University of Kentucky. 1968. Two subsequent articles are excellent: "Alfonso $X$ el Sabio compara moros y judios", Romanische Forschugen 82 (1970): 578-583; and "The Mostem in the Cantigas of Alfonso X, el Sabion, Kentucky Romance Quarterly $20(1973): 173-207$. The First international Symposium on the Cantigas of Santa Maria of Alfonso $X$, el Sabio was held recently at the Spanish Institute, New York City. A journal has been established and will shortly appear: Butlletin of "Cantigueros de Santa Maria" from the University of Kentucky, and will carry all information about the Cantigas

(2) BAGBY'S central dissertation thesis revolves around the dual concept of the Moor as both political and religious adversary. He inevitably locates the animus for this hatred, however, in religion. He has developed his own categorization, discerning four major negative presentations of the Moor in the canticles: (1) militant invader; (2) traitor; (3) pagan and (4) cruel prosecutor of captives.

(3) In his article "Alfonso $X$ el Sabio compara moros y jdíos", BAGBY has noted that Alfonso rejected both Muslims and Jews socially. The Muslim is depicted as an undesirable, a barbarian, a sacker, a politico- 
It seems inevitable in this instance that we allude, however briefly, to Americo Castro's highly controversial theory about the semitization of Hispanic society. It is not unreasonable to mention that historical confrontation with large, sophisticated, and, in some ways, culturally superior non-western, nonChristian societies could not leave some impress (Castro, Realidad 182-186). It is, however, equally reasonable to claim that Spanish or Castifian society developed a unique set of values in confrontation with Muslims and Jews. It is important to bear in mind that specifically Muslim and Jewish values were overtly and categorically rejected (Payne 139).

In addition to Alfonso's personal political ambition, presumably drawn from the magnificent impulse his father had given to the Reconquest (del Río 55), the conditions of the times had equally kindled his legalistic spirit. Both in matters regarding his own kingship or the rights of the community, he assumed, in an inalienable fashion, the legislative function of the kingdom. But whether through legislation passed to quell opposition from his fractious nobility (a major reason for the creation of the Siete Partidas) or direct campaigns against the usurping infidel, Alfonso inevitably sought to bolster his own political position (Gimeno 35). And it is this political desire, inexorably bound to his religious feelings, which shaped his attitude toward the Muslim invader.

The principal concern of this brief study is an examination of Alfonso's presentation of the Muslim character in the Cantigas. This volume of work, as a whole, represents not merely a study of medieval folklore, but an extensive catalogue of historical and daily occurrences and customs (Keller, Pious 82). Every conceivable member of Spanish contemporary society is present here, from king to the lowest peasant; the clergy, the court, the country are all recorded. It certainly is reasonable to believe that Alfonso expended more time and money on the production of the Cantigas than on any of his other contributions (Keller, Alfonso 64). But this aims were not purely cultural, although the Cantigas remain a monumental literary, artistic and musical enterprise. His chief aim seems to have been didactic, a valiant attempt to teach a rough society the virtues - and eventual rewards - of Christianity and the dependence upon divine grace. Keller's well taken point that the Cantigas are of the king's personal authorship, especially those written in the first person, further illustrates the king's Christian commitment (Keller, Pious 84).

Inspired by the religious pilgrimages as well as the crusades of the times, Alfonso sees the two blend in a clear image of spiritual conquest. And if politically it is a time of annexations and desire for far-away kingdoms, the religious goals are hopelessly intertwined in this endeavor (Filgueira xix). In short, the goals are virtually one and the same. Thus the political enemy is created as a larger than life villain, and he remains an inveterate religious foe as well.

religjous invader. The Jew, on the other hand, is someone undeserving of confidence because his only loyalty is to himself and his ethnic group. His avarice transcends any other consideration. 
Keller has noted that it is a virtually impossible task to catalogue the Cantigas by motif (Keller, Alfonso 32); however, the following simplified categorization will serve our present purposes. The three significant attitudes the king expresses toward Moslems in the five canticles to be discussed are conversionary, spiritual superiority of Christianity, and temporary Moslem superiority, on a physical level, primarily seen as a Christian punishment for sinning. We might add to this, however, that although Muslim presence in Spanish territory was seen as (possible) Christian punishment, the idea of warring upon the infidel, even outside Hispanic territory, was considered perfectly licit. The Virgin never lacked for booty on such expeditions (Procter 29 ).

Americo Castro suggests that Alfonso did discern a difference between faith and territorial aggrandisement, and envisioned the Muslim more as a political rival than a religious rival (Castro, Structure 226). This in itself is more than passingly confusing, due to the peculiar juxtaposition of religion and politics in Spain at this time. Intolerance, as he seen it, was not present in the same degree in thirteenth-century Spain as in later centuries. To illustrate this quasi-acceptance of non-Christian religions, Castro draws upon characterizations of Moslems (and Jews) in the Cantigas. He cites the case of a king of Morocco who defeats his enemy with the help of the banner of the Virgin (no. 181). The Moors bring back from the sea, into which they had cast it, an image of the Virgin, so they may catch fish once more (no. 183).

A thorough study of these canticles produces quite contrary conclusions. It must be understood that superficial positive characterizations often belie an opposite intent, and one simple cannot take the message at face value, but must examine it in its entirety if he is to arrive at Alfonso's specific meaning.

In reality, Cantiga 181 is an exaltation of the True Faith. The king of Morocco is advised to display the banner of the Virgin and to rest assured that in so doing he will defeat his enemies. He follows this advice, and when his (Moslem) enemies see the banner they become so frightened that, despite their military superiority, they give up the struggle.

Technically, the Muslim group who momentarily enjoyed the Virgin's favor were not formal converts. But the true intent of this canticle is a paean to the Christian religion and its ultimate superiority over all men. Castro certainly exaggerates to the limit any suggestion that this story demonstrates tolerance, or, more to the point, respect for the integrity of the Muslim faith.

Canticle 183, written in the first person, is composed of purely negative elements. It even goes so far to speak of the "evil Muslim race". The Muslims are disgruntled at seeing an image of the Virgin that the Christians have left behind in a castle in Faro. Enraged, they finally hurl it into the sea in an attitude of contempt. The Virgin, as a punishment, makes it impossible for them to catch any fish as long as the image remains in the water. The Muslims, realizing their error - but only insofar as having heaved the image into the sea- pull it out. They are then "rewarded" by the Virgin who permits them to fish again. 
Castro's view of this account as favorable, or even an impartial treatment of the Muslim faith, is not in keeping with his impeccable, if controversial, scholarship. Neither of these canticles bolsters his contentions, but both lend extensive support to our present supposition that the king ever regarded the Muslims as his religious and political enemies. Bagby quite correctly observes that if Castro had looked at these canticles in their entirety, rather than merely the conclusions, he would have been less inclined to see toleration where none existed (Bagby, "Moslem» 175).

Alfonso $X$ was admittedly a man of many dimensions and interests. But it is not the sensitive poet who pointedly illustrates the Moslem character in the Cantigas. Wishing to delineate and magnify the infidel in didactic Christian example, the king assumed the role of political and religious adversary who sought to drive Islam from the confines of his realm. Ever mindful of his faith, he was vitally concerned with the necessity of proving his religious superiority over that of his political enemies. In this era of incipient religious protonationalism, it is understandable why Alfonso chose to depict the Moslem as enemy in the canticles (Bagby, "Moslem" 176).

The Moslem as convert. - In the Siete Partidas Alfonso clearly states how Christians should convert Moslems. This was to be accomplished without the use of force, but with the persuasion of reason (Siete Partidas, V. IV, 343). Perhaps he patterned his vision of divine conversion on the same ideal.

Cantiga 28, told in the first person, relates to the siege of Constantinople by the Moors. Once, when Constantinople is in Christian hands, a Moslem sultan tries to invade the city with a uhost of pagans". And he begins to announce that he will raze the city and annihilate its inhabitants so that he might make off with the hidden treasure.

At this time Saint Germain is living in the city, and he begins to implore the Virgin to intercede and help the beleaguered citizens. The Virgin is moved to save the city, and the people are encouraged to light candles to her image, in praise of her divine aid. But the sultan, unmoved by this display, merely responds in terms of archers and the increased violence of warfare. Despite his efforts, eventually an entire legion of saints descends, accompanied by the Holy Mother and she (again) saves the city.

The sultan then raises his eyes to heaven to call upon that false prophet, Mohammad, but instead he sees the Virgin. When he becomes aware of this vision, he seems to realize that he has been a sinner, and that such intervention is truly of the Christian God. Duly convinced, he decides to become a convert.

Whether the sultan is truly reformed at the time of his conversion or merely goes through the motions, this canticle serves as a perfect forum for invective against the Muslim religion. At various stages of relating, the sultan is referred to as a cunning Moor, a thick-lipped and bearded Moor, and the follower of a known false prophet. 
The skepticism regarding his intent in baptism seems to be graphically confirmed in the last panel of the miniatures, in which we observe the slightly incongruous figure of the full-grown Muslim chieftan immersed in the font, a somewhat embarrassed expression on his lips (Guerrero Lam. 33).

Cantiga 46, written in the first person, is the story of a Moor who sails across the seas to ravage Christian lands, and returns to his own land to divide the booty. For himself he selects to keep an image of the Virgin, which he examines carefully and then orders to be put away. He does not really accept the possibility that God could ever have been made man, and thus walk among men as any other mortal. He. is, however, prepared to retract this view should God agree to give him proof of the validity of Christian doctrine.

Such proof is shortly offered to him, and he is permitted to see that the breasts on his image of the Virgin actually give milk. Witnessing this miracle, he begins to cry, then arranges for a priest to baptize him. Following this event, he has his entire family baptized, and performs many other good works.

This canticle traces three major stages of development. Devotion by a Moor to Mary, the miracle of God's answer through the physical evidence of the milk itself, and, most importantly, the conversion of the Moor in the irrefutable evidence of Christian truth. The underlying theme is that, all along, this Moor has been a "good" Moor, someone singled out for salvation and God's blessing precisely because he was capable of honest belief.

A second, and perhaps more subtle, intent resides in a desire to denigrate Islam even as it glorifies and edifies the individual Moor in his ready acceptance of the True Faith. His gentle conversion is brought about by divine intervention. His doubts dissolve in the face of this revelation, and his conversion and baptism are almost simultaneous.

In the third panel of the miniatures, where the booty is being divided, the Moor has a pronounced "Arabic" look, although the nose is not unusually prominent. In each succeeding panel, as the miracle unfolds, his features become more occidentalized, until the last panel where he takes on a full "Christian" appearance (Guerrero Lam. 52).

Cantiga 167 relates how a Moorish woman of Borja took her dead son before an image of the Holy Mother in Salas. This is another lesson of faith in which the Moorish woman must exercise great courage in order to turn away from her own people and religion. Enduring scorn from the other Moorish women, she overcomes their contempt in her belief in the Virgin's powers. Persuaded that the Holy Mother can resurrect her dead son, she represents a mother's love reduced to the lowest theological common denominator. After three days the child is, indeed, brought back to life, and she becomes a convert. This is an example of a favor conceded by the Virgin to a "good" or "worthys Muslim. 
While it was the Virgin's miracle that brought the Moorish woman to conversion, the character that Alfonso has presented is one of a Moslem who was so eager to believe that she resisted the taunts of her former coreligionists. This, in itself, can be seen as evidence of honorable intentions on her part toward the Christian religion.

In the first panel of the miniatures, she seems to stand out with her dark hair and Moorish features. But the last panel, the scene of her baptism, reflects her hair as substantially lighter in tone and her features more occidentalized (Guerrero Lam. 83).

The religious superiority of Christianity. - In the Siete Partidas, a work which represents a desire for cultural as well as legislative cohesiveness on Alfonso's part, he clearly states that the Muslims have an erroneus faith and follow a false prophet. They are blind in their obstinacy and stubborn in their resistance of the True Faith (Siete Partidas, v. IV, 343).

Cantiga 192, related in the first person, treats the example of how the Virgin freed a Moor who was held captive in Consuegra through the power of the devil. A Christian man continually lectures his Moorish captive on the goodness of the Virgin, even in the face of the Moslem's claims that her power is worthless. One night the man sends his captive to a special area of the warehouse and admonishes him to lie down. While he is engaged in this exercise, the devil takes possession of him, but the Moor defends himself valiantly. The devil returns on two successive nights, but on the third the Virgin comes and shows the true path to the captive. She embarks upon a bitter diatribe that, with reasonable assurance, reflects Alfonso's own views, telling him that he can only be saved by divorcing himself from that ufalse, vain and insane villain, that dog of a Mohammad». He must consent to be baptized a Christian. Such expressions are scarcely consistent with the image of the gentleness of the Holy Mother.

There appears to be a double didactic intent here. The obvious significance is that there is no hope of salvation for the followers of a denounced false prophet, and that such followers are inevitably doomed to perdition. A subtler thread is perceived as an exemplary lesson within Christianity itself, namely the pressing need to adhere loyally to the tenets of the faith if one is to be saved.

Although the Moor is depicted as dark-skinned throughout the panels, he does seem to be overtaken by a more sinister expression in panels two and three, presumably while he is being tormented by the devil. But such insidious look might equally be the physical illustration of the evil in following the Muslim faith which is, literally and figuratively, overseen by the devil. In the fifth and sixth panels the Moor shows a decidedly more peaceful countenance (Guerrero Lam. 210).

The Moslem as temporary victor in war or battles. - There may be more than fancy attached to the theory that Alfonso thought Moorish possession 
of Spanish lands an act of divine punishment. The king accepted with alacrity his role as adversary to the Moors, and the resulting position of champion of Spain, from his first intervention in a war in 1237 (Solalinde 7). At that time, at the tender age of sixteen, he was already seen aiding his father's conquest of Andalusian lands. This role is further evidenced by Alfonso as author of the canticles. In the 401 st canticle he somewhat facetiously, albeit not irreverently, asks the Virgin to intercede for him although he has written but little in her honor. At this time he specifically requests her aid in destroying the Moors and driving them out of Spain.

Cantiga 99 demonstrates how the Holy Mother destroys a great multitude of Moors who have entered a Christian city and want to destroy the images. Told in the first person, the tale relates how the Moors, militarily superior, overtake a Christian city with the idea of destroying the images and the altar on which God was worshipped. They see a particular image that seems more beautiful than the others and rush to destroy it. But the Virgin, judging that the Christians had endured enough, will not permit it, nor will she allow the Moslems to reach it or injure it an any way. Thus they learn God's displeasure at their (Moorish) attempt to desecrate a holy place and mock the Christian faith.

The true Christian image is made invulnerable, just at the moment that the Christians are despairing. In final analysis, the Moors are unable to wreak their vengeance on this house of worship's greatest treasure. The story depicts the Moors as agressors against the True Faith, and that God, despite the sinning, is ultimately on the side of the Christians. A more subtle didactic intent of this canticle may be the reinforcement of the Christian tenet that God always forgives the sinner.

Although such conclusions are admittedly subjective, it must be noted that in the miniatures the Moorish forces seem to largely outmumber the Christian, who, in turn, seem more bemused than anything else. The faces of the Moors, where these are clearly depicted, seem to belie a kind of snickering cynicism. They appear to be better armed, a fact which gives even more weighty importance to their defeat, through divine intervention, at Christian hands (Guerrero Lam. 110).

Beyond anything else, Alfonso was concerned with endowing spiritual unity to his domains. His vision was at once universalist and narrow (Ayerbe 2), not unlike that shared by his successors to Castile, the Catholic Monarchs. And like those later visionaries, Alfonso was also intent on the Reconquest.

His attitude toward the Moslem could be violent, not only in the field of battle, but in legislation and letters as well (4). Solalinde has metaphorically

14) In Partida VII (Title $X X V$, Law 10) this is particuiarly evident. This section treats the punishment of any Muslim who becomes "involved" with a Christian woman. If she is an unmarried woman (presumably young), his punishment, as well as hers, at the first offense is stoning. If she repeats the offense, she 
concluded that although Alfonso engaged in the study of astrology - a science, if not imported from, at least enhanced by the Arabs - he never abandoned earthly concerns (Solalinde 20). We must necessarily deduce that, however much Alfonso might have been indebted to Islam in matters of learning -and the depth of regard cannot be measured with any accuracy - he was always conscious of the erroneous source from which such superficial information emanated.

\section{LIST OF WORKS CITED}

ALFONSO X, el Sabio. Las Siete Partidas del Sabio Rey Alfonso. Barcelona: Imprenta de Antonio Bergnes, 1844 AYERBE-CHAUX, REINALDO, ed. Estoria de España. Madrid: José Porrúa Turanzas, S. A., 1982.

BAGBY, ALBERT I. "Alfonso $X$, el Sabio compara moros y judios". Romanische forschungen 82 (1970): $578-583$.

- "The Moor and the Jew in the Cantigas of Alfonso X, el Sabion. Ph. D. dissertation, University of Kentucky, 1968

- "The Moslem in the Cantigas of Alfonso X, el Sabio". Kentucky Ramance Quarterly 20 (1973): 173-207.

CASTRO, AMERICO. La Realidad historica de España. México: Editorial Porrua, S.A., 1966.

- The Structure of Spanish History. Princeton: The University of Princeton Press, 1954.

DEL RIO, ANGEL. Historia de la literatura española. New York: Dryden Press, 1948.

FILGUEIRA VALVERDE, JOSÉ, ed., Las Cantigas de Santa María. Madrid: Editorial Castalia, 1985.

GIMENO CASALDUERO, JOAQUÍN. La Imagen del Monarca en la Castilla del siglo XIV. Madrid: Revista de Occidente, S. A., 1972

GUERRERO LOVILLO, JOSÉ. Las Cantigas. Madrid: Consejo Superior de Investigacionés Cientificas, 1949.

KELLER, JOHN ESTEN. Alfonso $X$, el Sabio. New York: Twayne Publishers, Inc. , 1967.

- Pious Brief Narrative in Medieval Castilian and Galician Verse. Kentucky: The University Press of Ken tucky, 1978.

PAYNE, STANLEY G. A history of Spain and Portugual. Madison: The University of Wisconsin Press, 1973

PROCTER, EVELYN S. Alfonso $X$ of Castile. Oxford: the Clarendon Press, 1951

SOLALINDE, ANTONIO G. Alfonso X, el Sabio. Madrid: Colección Granada, 1922.

is to be executed and her heirs disinherited through the loss of her possessions. This equally applies to the widow. If this crime involves a married woman, she is to be stoned and remanded to the custody of her husband. He is then authorized to burn her, release her, or do with her what he chooses. And should a Muslim uinvolven himself with a disgraced (ufallen") woman, at the first offense they were to be displayed before the city; execution is prescribed for the second offense.

The law obviously was written to prevent women from degenerating into the heinous crime of consorting with Muslims. There could be no baser offense for a Christian woman, unmarried, married or widowed. Even common women were enjoined against frater rizing with Muslims lest they invite violent punishment 